\title{
EXPORT OF MATERIALS ALONG A TIDAL RIVER CHANNEL THAT LINKS A COASTAL LAGOON TO THE ADJACENT SEA
}

\author{
Javier Aldeco Ramírez, ${ }^{1,}$, Martha Signoret Poillon ${ }^{2}$, \\ María Adela Monreal Gómez $z^{3}$ and David Alberto Salas de León ${ }^{4}$
}

${ }^{1,2}$ Universidad Autónoma Metropolitana Unidad Xochimilco - Departamento El Hombre y su Ambiente (Calz. del Hueso 1100, col. Villa Quietud, Coyoacán, 04960, México, D.F. México)

${ }^{3,4}$ Universidad Nacional Autónoma de México - Instituto de Ciencias del Mar y Limnología (Ciudad Universitaria s/n, 04510, México, D.F., México)

*Corresponding author: jaldeco@correo.xoc.uam.mx

\section{A B S T R ACT}

Intratidal variability and flux of salt, chlorophyll-a and suspended materials were evaluated in a shallow tropical tidal channel linking a coastal lagoon to the western Gulf of Mexico. Velocity, temperature and conductivity were used to calculate the fluxes. Data were recorded during three tidal velocity cycles (tvc) under extreme river discharge conditions. Chlorophyll-a and suspended materials were determined below the surface. In both seasons (dry and rainy), the flow was ebbdominated and with longer duration than when in flood. Maximum current velocities were $0.30 \mathrm{~m} \mathrm{~s}^{-1}$ in May (dry season) and $0.60 \mathrm{~m} \mathrm{~s}^{-1}$ in September (rainy season). In the dry season the mean chlorophyll-a export was of $7.56 \mathrm{Kg}$ over tvc while the import was of $3.32 \mathrm{Kg}$. In the rainy season mean export $(47.3 \mathrm{Kg}$ ) was 6 times greater than the import $(7.93 \mathrm{Kg}$ over tvc). Phytoplankton was dominated by organisms of marine origin. The mean of exported, suspended materials in the rainy season $(111.3 \mathrm{Kg})$ was 4.6 times greater $(859 \mathrm{Kg})$ than that in the dry season $(184.7 \mathrm{Kg}$ over tvc). Tidal velocity asymmetry is an effective mechanism of exportation, introducing relatively warm and saltier water into the river through the tidal channel.

\section{R ES UMO}

A variabilidade intramaré, o fluxo de salinidade, a clorofila-a e material em suspensão foram avaliados em um canal superficial de maré tropical em uma lagoa costeira ao oeste do Golfo do México. Os dados de velocidade, temperatura e condutividade foram usados para cálculo dos fluxos durante três ciclos de velocidades das marés (tvc) sob condições extremas de descarga. A Clorofila-a e material em suspensão foram determinados abaixo em subsuperfície. Em ambas as estações (seca e chuvosa), o fluxo dominante foi durante o refluxo e com duração maior durante o fluxo de entrada. A máxima velocidade encontrada foi $0.30 \mathrm{~m} \mathrm{~s}^{-1} \mathrm{em}$ maio (estação seca) e $0.60 \mathrm{~m} \mathrm{~s}^{-1}$ em setembro (estação chuvosa). Durante a época seca foram exportadas $7.56 \mathrm{Kg}$ de clorofila-a, enquanto a importação foi de $3.32 \mathrm{Kg}$. Durante a temporada de chuva a média exportada $(47.3 \mathrm{Kg})$ foi seis vezes maior que a importada $(7.93 \mathrm{Kg})$. A concentração media de material em suspensão exportado durante a época de chuvas $(111.3 \mathrm{Kg})$ foi 4.6 vezes maior $(859 \mathrm{Kg})$ que durante estação de seca $(184.7 \mathrm{Kg})$. A assimetria das marés é um mecanismo efetivo de transporte, introduzindo no rio águas relativamente quentes e mais salinas através do canal de maré.

Descriptors: Tidal channel, Intertidal variability, Salt, Chlorophyll-a, Suspended materials, Gulf of México.

Descriptors: Ambiente intermarés, Sais, Clorofila-a, Material em suspensão, Golfo do México.

\section{INTRODUCTION}

The structure and function of planktonic communities are governed to a large extent by physical forcing on different temporal and spatial scales (MANN; LAZIER, 2006). On small spatialtemporal scales hydrodynamic processes such as tides in the inlets of coastal lagoons and estuaries play an important role in the distribution and abundance of planktonic organisms (LUCAS et al., 1999, 2006;
MONBET, 1992). Tidal currents may be the major source of energy for transporting non-living materials and organisms as they are largely passively driven by these physical forces (LUCAS et al., 1999). Transport depends on differences in current magnitude and duration between ebb and flood tidal currents; such differences, "velocity asymmetry", are produced by the distortion of the tidal wave entering rivers, estuaries and coastal lagoons (HOITINK et al., 2003). Several studies have been conducted in Mexico on plankton transport by tidal currents. 
Gómez-Aguirre and Santoyo-Reyes (1975) examined the interaction with the sea at three estuaries in Northwestern Mexico, they pointed out that phytoplankton abundance diminished during high tide, associated with an inverse pattern of zooplankton. Another study in the southern Gulf of Mexico highlighted the importance of the tidal transport of the shrimp larvae by tidal forcing (FLORES-COTO et al., 2003). Studies carried out on the northwestern Mexican coast, in Magdalena Bay, showed that the horizontal transport of euphausids was modulated by semi-diurnal tidal currents at the mouth and that they are completely dispersed inside the bay by strong spring tidal currents (GÓMEZ-GUTIÉRREZ; ROBINSON, 2006). The behavior of the red crab Pleuroncodes planipes, in response to tidal variations at the entrance to this subtropical bay, is to modify their position in the water column according to the high or low tide water level (ROBINSON; GÓMEZAGUIRRE, 2004)

The dynamics of nutrients, chlorophylls, suspended materials and salt concentrations, in shallow coastal lagoons directly connected to the sea, have been widely studied and discussed (HSIEH et al., 2010; MOSER et al., 2005; PEREIRA-FILHO et al., 2001). The La Mata Channel presents an untypical morphologic feature; it is connected to the sea by means of the Tuxpan River. The mouth of the Tampamachoco Coastal Lagoon first exchanges mass with the river, through the La Mata Channel, and after that with the adjacent sea (Fig. 1a).

The aim of this research project is to analyze the intratidal variability and fluxes of water, salt, chlorophyll-a (Chl- $a$ ) and suspended materials (SM), in a narrow shallow tropical tidal channel, between a coastal lagoon and the adjacent sea connected through a river. The role of tidal velocity asymmetries in the horizontal transport through the tidal channel is also reviewed.

\section{Material and Methods}

\section{Area of Study}

La Mata is a narrow shallow tropical tidal channel with conspicuous hydrodynamic features, because it connects a coastal lagoon, a river and then the adjacent sea. This shallow "V" shaped channel is $1.5 \mathrm{~km}$ long and $\sim 300 \mathrm{~m}$ wide (Fig. $1 \mathrm{~b}$ ) with variable depth; a depth greater than $8 \mathrm{~m}$ is found at the point of direct connection with the Tuxpan River; in the middle of the channel the depth diminishes to $\sim 2.5 \mathrm{~m}$ and on the inner side to $\sim 1 \mathrm{~m}$. The regional climate is described as warm, subhumid, with a rainy summer season. During May winds are light and occasionally a strong southerly wind is observed; in summer the humid, warm trade wind prevails in the region;
September is the rainiest month of the year $(\sim 310.6$ mm) (SÁNCHEZ-SANTILLÁN et al., 1997).

\section{Sampling Strategies}

A fixed sampling point was established on the western margin of the La Mata Channel (Fig. 1b). Chl-a and SM were sampled simultaneously on two days in May and three in September, 1990, at 2-hourly intervals, beginning - on both campaigns - at $10.00 \mathrm{~h}$; the depth at this sampling point was $1.5 \mathrm{~m}$, so samples were only taken below the surface. An acoustic current meter ACM-2 (Neil Brown Instrument Systems) was moored in the middle of the channel $\left(20^{\circ} 58.33^{\prime} \mathrm{N}\right.$, 97 $20.164^{\prime}$ ) (Fig. 1c). This current meter registered the current velocity every 10 minutes ( $\mathrm{u}$ and $\mathrm{v}$ velocity components in $\mathrm{m} \mathrm{s}^{-1}$ referenced to the magnetic North), temperature $\left({ }^{\circ} \mathrm{C}\right)$ and conductivity $(\mathrm{mS})$.

In order to obtain the normal and alongchannel velocity components, the current meter components were projected onto a coordinate system the axis of which was rotated $298^{\circ}$ clockwise with reference to the magnetic North, thus the new u- and v- velocity components were, respectively, normal to and along the La Mata Channel. In order to obtain the same number of water elevations and correlate them with the current meter data (every 10 minutes), water elevation data were splined following Conte and Boor's (1972) procedure. The time of flood (inflow) or ebb (outflow) was noted from the v-velocity component flow graph when a zero-up-crossing or zero-down-crossing was seen in the velocity values.

Water samples were obtained every $2 \mathrm{~h}$ with $5 \mathrm{~L}$ van Dorn bottles to determine Chl- $a$ and SM concentration. For Chl- $a$ half a liter was filtered through Whatman GF/F filters (glass filters, pore size $0.7 \mu \mathrm{m})$, previously filtered through a $200 \mu \mathrm{m}$ mesh in order to eliminate zooplankton organisms. Chl- $a(\mathrm{mg}$ $\mathrm{m}^{-3}$ ) was determined following Lorenzen's (1967) spectrophotometric method using a Milton Roy Spectronic 21 spectrophotometer and pigment extraction with $90 \%$ acetone. For SM mg L $\mathrm{L}^{-1}$, half a litter was filtered through precombusted and preweighed Whatman GF/F filters; the filters were dried at $70^{\circ} \mathrm{C}$ and weighed. Data of chlorophyll-a and SM concentration were also cubic splined, so interpolated data were separated by half-hourly intervals. Water samples of $250 \mathrm{ml}$ for phytoplankton qualitative analysis were collected at the surface with a van Dorn bottle and fixed with Lugol's iodine solution. General phytoplankton composition was analyzed with an Axiovert Zeiss inverted microscope and settlement chambers of $25 \mathrm{~cm}^{3}$. Identification was carried out mainly based on Tomas's (1997) manual. Organic suspended matter was not analyzed because our first approach was to evaluate the net flux of total suspended materials through the La Mata Channel. 

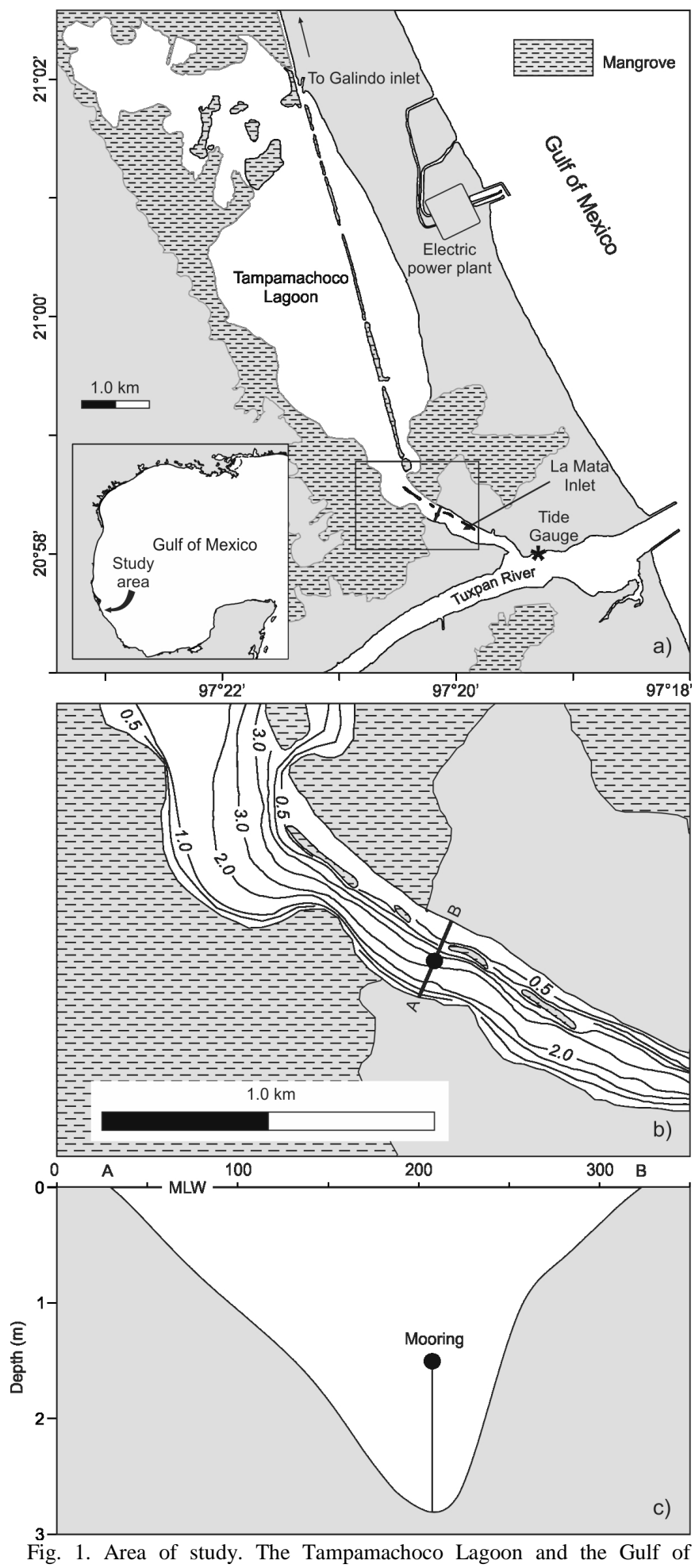

Mexico(a), the La Mata Channel (b) and Current-meter mooring (c) 
The cross sectional area of the channel was computed taking into account the tide water level; thus the area varied according to the height of the tide.

To achieve the integration of mass importation or exportation of Chl- $a$ and SM towards (positive values) or away from (negative values) the coastal lagoon, graphical integration was performed with the following data: on the abscissa axis was set the date in 0.1 day intervals versus chlorophyll- $a$ (mg $\left.\mathrm{m}^{-3}\right)$, suspended materials $\left(\mathrm{mg} \mathrm{L}^{-1}\right)$, and the corresponding value of water flow $\left(\mathrm{m}^{3} \mathrm{~s}^{-1}\right)$ on the ordinate axis.

The water flows were computed according to: $\int d Q_{i}=\int A_{i} d V_{i}$ where $i$ is the number of time-step integration, $Q_{i}$ the water flow $\left(\mathrm{m}^{3} \mathrm{~s}^{-1}\right), A_{i}$ the cross sectional area $\left(\mathrm{m}^{2}\right)$ and $V_{i}$ the instantaneous velocity $\left(\mathrm{m} \mathrm{s}^{-1}\right)$ along the channel. The instantaneous fluxes $\left(F_{i}\right)$ were obtained by multiplying $Q_{i}$ by the time corresponding concentration, $C_{i}$, of salt $\left(\mathrm{Kg} \mathrm{m}^{-3}\right)$, Chl$a\left(\mathrm{mg} \mathrm{m}^{-3}\right), \mathrm{SM}\left(\mathrm{mg} \mathrm{L}^{-1}\right)$, and thus $F_{i}=Q_{i} C_{i}\left(\mathrm{Kg} \mathrm{s}^{-1}\right)$. The net mass exported/imported $\left(M_{e i}\right.$; absolute value) results from the integration of the mass flux differentials: $\left|M_{e i}\right|=\int F_{i} d t$, where the integral limits $t=0$ and $t=\alpha$ were two followed zero velocity upcrossing time, $\mathrm{dt}$ was the time interval, 10 minutes for salt, and $0.1 \mathrm{~d}(2.4 \mathrm{~h})$ for Chl- $a$ and SM. Mass was the amount of salt, Chl- $a$ or SM that is moved through the La Mata Channel during each velocity cycle. The results of the exchanges were separated into import (inwards) and export (outwards) through the channel according to the sign of the water velocity (Fig. 5). Time integration of water, salt, Chl- $a$ and SM from time series were calculated over three water flow cycles.

\section{REsults}

Water temperature ranged from $25.5^{\circ} \mathrm{C}$ to $28.5^{\circ} \mathrm{C}$ in May (Fig. 2a) and from $27^{\circ} \mathrm{C}$ to $31.8^{\circ} \mathrm{C}$ in September (Fig. 2b). Temperature values were consistent with the locality and season as previously observed by Contreras (1983).

Current meter salinity ranged from 28.4 to 36.5 in May (Fig. 2c), and from 17.9 to 29.7 in September (Fig. 2d).

Chlorophyll- $a$ showed a mean concentration of $3.76 \mathrm{mg} \mathrm{m}^{-3}$, ranging from $1.54 \mathrm{mg} \mathrm{m}^{-3}$ to $7.23 \mathrm{mg}$ $\mathrm{m}^{-3}$ in May (Fig. 2e), and a mean concentration of 2.48 $\mathrm{mg} \mathrm{m}^{-3}$, ranging from $0.51 \mathrm{mg} \mathrm{m}^{-3}$ to $6.33 \mathrm{mg} \mathrm{m}^{-3}$ in September (Fig. 2f). These values were of the same order as those found in Southern San Francisco Bay, a subtropical environment (LUCAS et al., 1999), but lower than previously reported for the Tampamachoco Coastal Lagoon (SÁNCHEZ-SANTILLÁN et al., 1997). Chl- $a$ concentrations oscillated from 2.7 to 7.2 $\mathrm{mg} \mathrm{m}^{-3}$ and correspond to an $\alpha$ mesotrophic condition, common in other Gulf of Mexico coastal lagoons (CONTRERAS-ESPINOZA et al., 1994).

No clear oscillation patterns were detected for chlorophyll-a concentration in May (Fig. 2e), and in September the highest values were found at the end of the ebb tide phases (Fig. 2f). Overlapping graphs of Chl- $a$ concentration and water velocity (Fig. 2f) show a similar pattern.

SM showed a mean concentration of 22.8 $\mathrm{mg} \mathrm{L}^{-1}$, ranging from 10.3 to $53.7 \mathrm{mg} \mathrm{L}^{-1}$ in May (Fig. $2 \mathrm{~g}$ ), and a mean of $45 \mathrm{mg} \mathrm{L}^{-1}$, ranging from 13.5 to $95.2 \mathrm{mg} \mathrm{L}^{-1}$ in September (Fig. 2h). These values were of the same order as those detected in the tropical estuarine system of São Vicente and Santos estuarine channels (Brazil) (MOSER et al., 2005). During high freshwater runoff (September), high concentrations occur over a longer duration of ebb phases, showing net suspended material transport from the lagoon to the river. The high concentrations during the ebb tides result from the increased friction with the sea bed caused by variations in water depth; on the inner side of the channel the bed is $1 \mathrm{~m}$ deep, and in the direct connection with the Tuxpan River more than $8 \mathrm{~m}$. Values of SM showed erratic fluctuations (Fig. 2g; 2h). In September, in the second and third flow cycles, the highest values were found at the end of the ebb phase, resulting from the re-suspension of sediments by the action of the tidal current. Overlapping graphs of suspended material and water velocity (Fig. $2 \mathrm{~g} ; 2 \mathrm{~h}$ ) for the sampling periods of May and September show no clear dependence on water velocity.

The discharge from the Tuxpan River basin into the Gulf of Mexico is considered, according to CONAGUA (2010), to be the $12^{\text {th }}$ in importance (in volume). During 1990 the Tuxpan River presented a discharge that ranged between 250 and $2100 \mathrm{~m}^{3} \mathrm{~s}^{-1}$ (Fig. 3). Time series of the Tuxpan River discharge show peaks that may be associated with meteorological conditions such as the northerly wind that brings humid air or summer storms, but an envelop depicts a low river discharge for the first half of the year, and a paused increase up to a maximum of around days 270-280, corresponding to September (Fig. 3). The sampling times discussed in this paper fall into extreme periods of low river discharges and around maximum river discharges.

Data from the tide gauge close to the Tuxpan River mouth (SMU, 2010) showed a tide height of 0.7 $\mathrm{m}$ of diurnal shape for the May sampling lapse (Fig. 4a). During the September sampling (Fig. 4b), the first half of the water level curve depicted a mixed tide, then changed to roughly diurnal; tide height was around $0.5 \mathrm{~m}$ in the mixed part and $0.6 \mathrm{~m}$ in the diurnal part. 

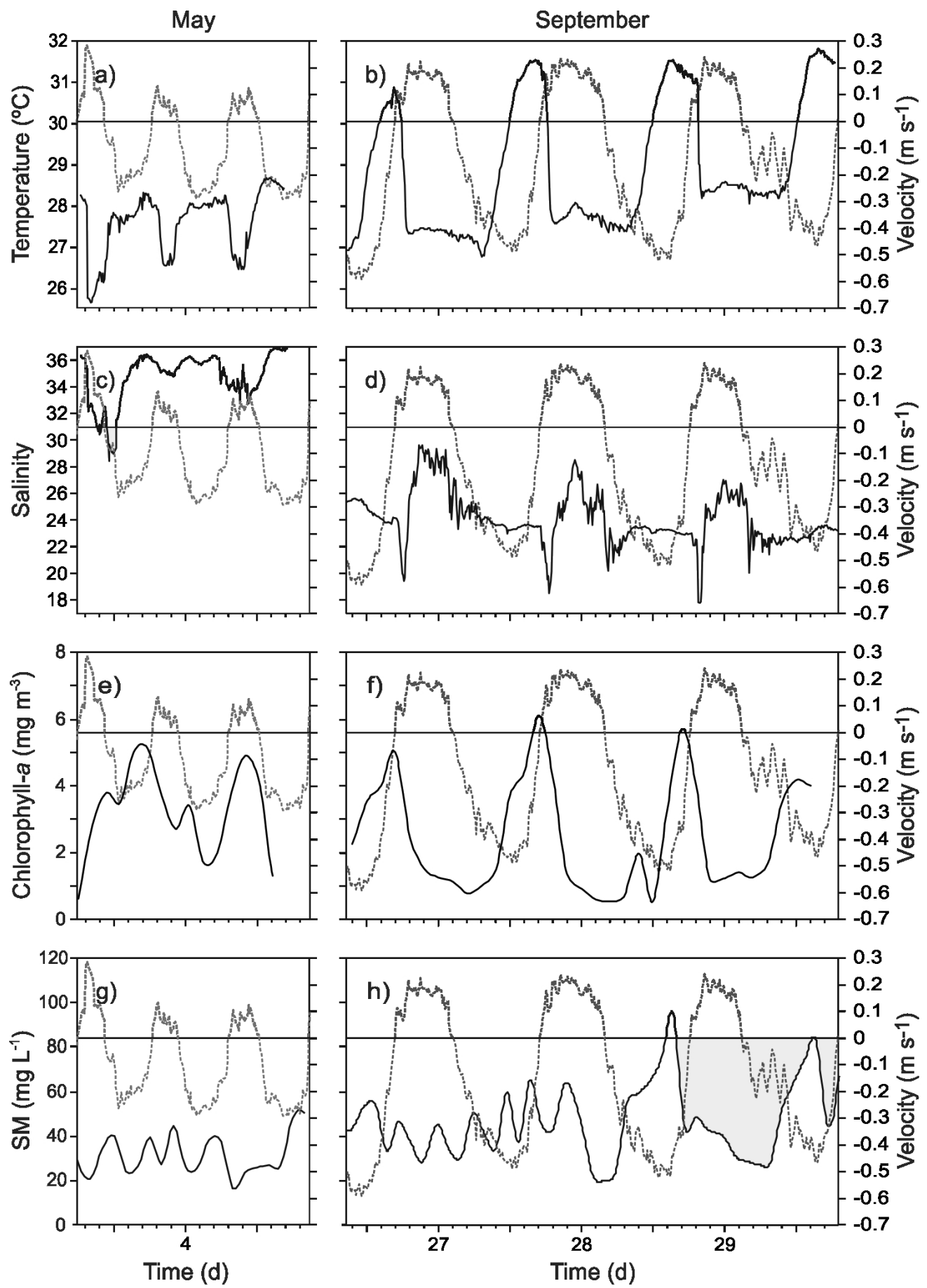

Fig. 2. Left panel for May Temperature (a), Salinity (c), Chlorophyll- $a$ (e) and Suspended materials (SM) (g). Right panel for September Temperature (b), Salinity (d), Chlorophyll- $a$ (f) and Suspended materials (SM) (h); variables are in dark lines. Velocity, in dotted lines, is represented with positive values for flood, and negative values for ebb. 


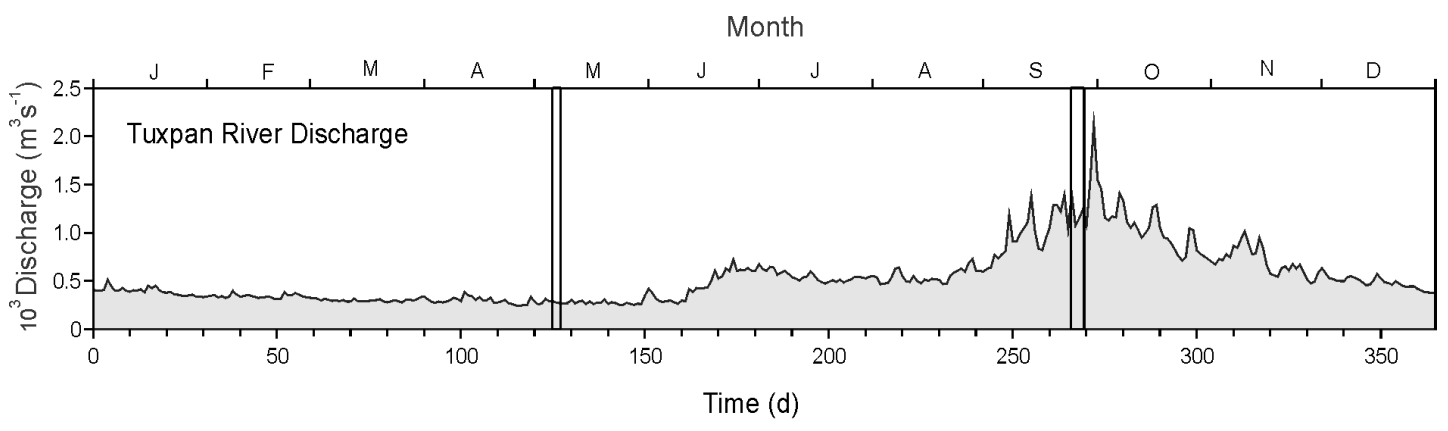

Fig. 3. Tuxpan River discharge in 1990. Vertical lines indicate sampling periods in May and September.
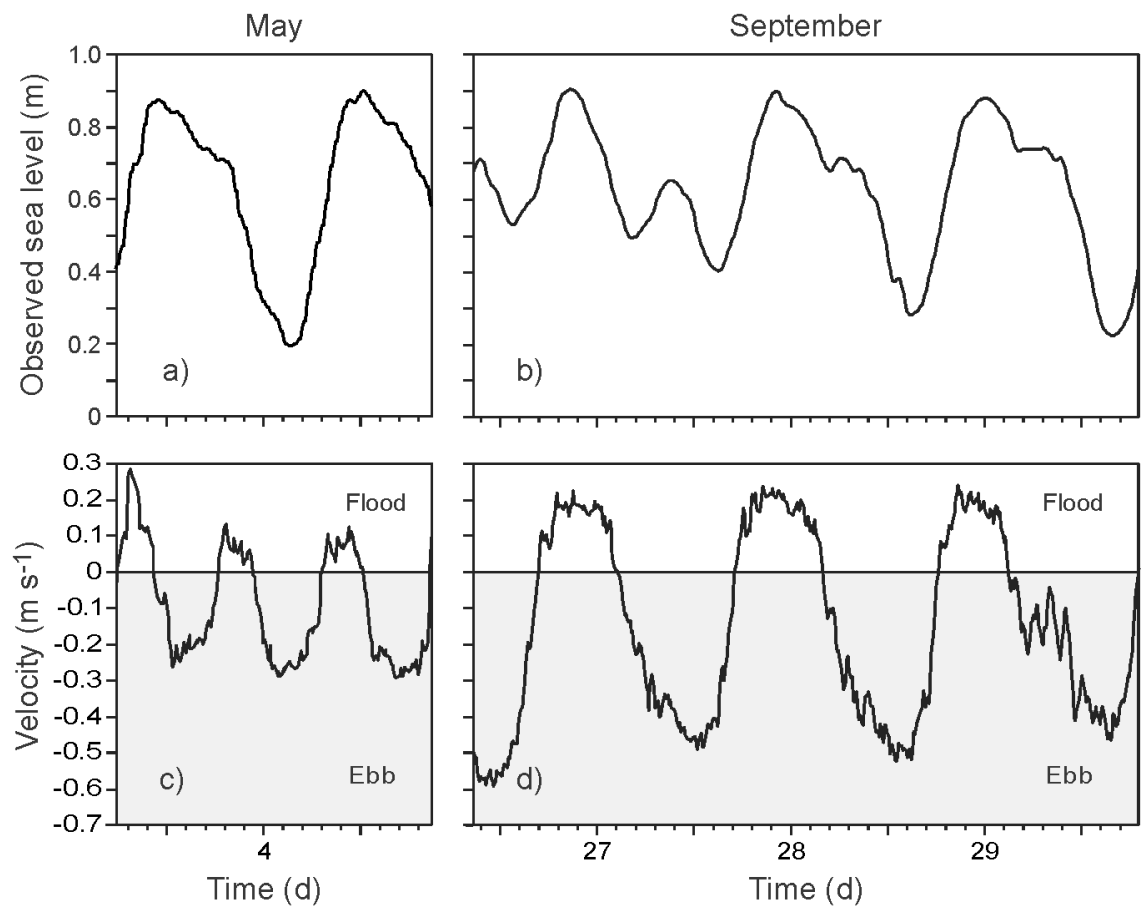

Fig. 4. Sea level (m) for May (a), and September (b). Current velocity ( $\mathrm{m} \mathrm{s}^{-1}$ ) for May (c), and September (d).

Tidal current velocities along the channel ranged between $-0.30 \mathrm{~m} \mathrm{~s}^{-1}$ and $0.29 \mathrm{~m} \mathrm{~s}^{-1}$ in May (Fig. 4c) and between $-0.60 \mathrm{~m} \mathrm{~s}^{-1}$ and $0.23 \mathrm{~m} \mathrm{~s}^{-1}$ in September (Fig. 4d). In both seasons, dry and rainy, the flow was ebb-dominated. Water outflows showed that ebb water volumes were up to twice those of the inflow (Fig 4; Table 1). Comparing the ebb current in the two seasons, it was observed that in the rainy season (September), ebb velocities were up to twice those registered in May.

Results showed that a greater volume of water flows from the lagoon to the river, going out faster and for longer than the entrance of water into the lagoon (Figs 4c and 4d; Table 1). Net water transport depends on the difference in magnitude and duration between ebb and flood tidal currents; such a difference, known as "tidal current asymmetry", is generally associated with the distortion of the tidal wave entering rivers, estuaries and coastal lagoons (HOITINK et al., 2003). Furthermore, in the La Mata Channel, the freshwater discharge from the microbasin, and likely salty water from the Galindo inlet (Fig. 1a), might also contribute to the ebb asymmetry.

Computation results of the mass of salt imported or exported during three velocity cycles of May and September are presented in Table 1 and Figure 5. It is clear that in the September diurnal cycles, the amount of salt that leaves the lagoon is 
greater than it is in May. From the maximum value of salt export, S2 (ebb) in September, and the minimum inflow value, M2 (flood) in May (Table 1), average salt fluxes were computed from the quotient of the amount of salt divided by the duration of the process (ebb or flood; Table 1). For S2 (ebb) the result was
5.92 Tons $\mathrm{s}^{-1}$, and for M2 (flood) was 1.34 Tons s $^{-1}$. The result obtained by Dyer et al. (1992), in a tropical estuary of Sungai Merbok (a mangrove-fringed system of Malaysia), was 3.8 Tons $\mathrm{s}^{-1}$ for an average salt discharge from a fifteen-day experiment in June, thus corroborating the magnitudes of our calculations.
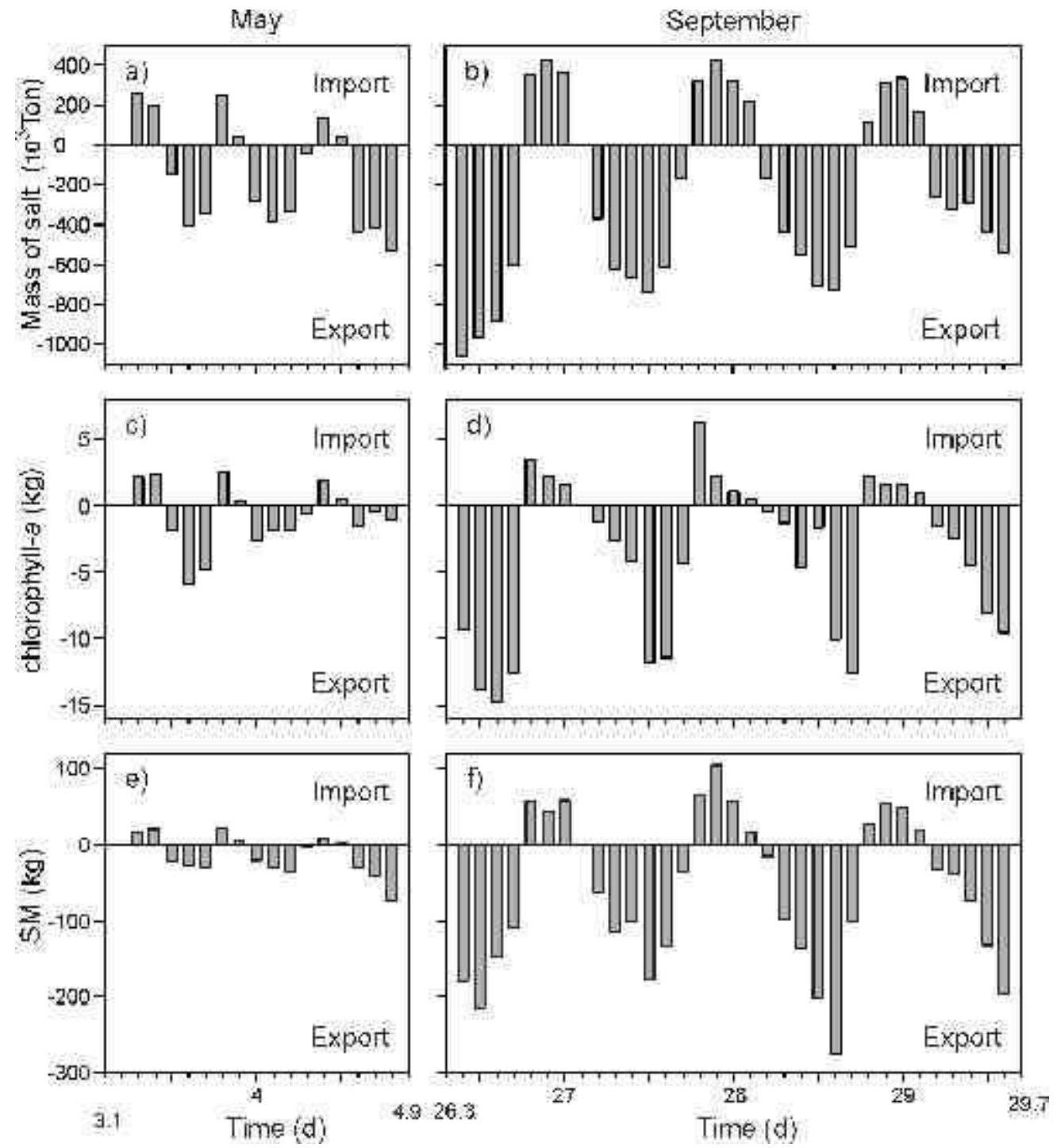

Fig. 5. Net-transport of Mass. Left panel for May Salt (a), Chlorophyll- $a$ (c) and Suspended Materials (SM) (e). Right panel for September Salt (b), Chlorophyll- $a$ (d) and Suspended Materials (sm) (f). 
Table 1. Water flow volumes and duration of ebbs (negative values) and floods (positive values), and salt in three water flow cycles within the La Mata Channel for May and September 1990.

\begin{tabular}{ccccrr} 
Month & Process & Duration (h) & Volume $\mathbf{( m}^{\mathbf{3}}$ ) & Salt (Ton) \\
\hline \multirow{6}{*}{ May } & M1 & flood & 4.00 & $+1,206,223$ & $38,843.70$ \\
& M1 & ebb & 7.00 & $-2,517,097$ & $78,302.10$ \\
& M2 & flood & 3.83 & $+516,867$ & $18,534.20$ \\
& M2 & ebb & 7.83 & $-2,590,994$ & $114,304.90$ \\
& M3 & flood & 4.50 & $+627,590$ & 20320.4 \\
& M3 & ebb & 7.17 & $-3,668,622$ & $121,745.40$ \\
\hline \multirow{6}{*}{ Sep } & S1 & flood & 10.01 & $+4,691,094$ & $117,158.70$ \\
& S1 & ebb & 14.35 & $-13,951,416$ & $301,355.40$ \\
& S2 & flood & 11.01 & $+5,766,068$ & $132,337.20$ \\
& S2 & ebb & 14.35 & $-14,710,355$ & $306,050.20$ \\
& S3 & flood & 8.51 & $+4,369,264$ & $97,975.50$ \\
& S3 & ebb & 16.18 & $-11,333,994$ & $233,485.00$ \\
\hline
\end{tabular}

In both seasons, Chl- $a$ fluxes were higher in ebb phases for the three flow cycles, especially in September (Table 2; Fig. 5). In May the total export was of $22.67 \mathrm{Kg}$ and the import of $9.96 \mathrm{Kg}$. In September the total export was of $141.98 \mathrm{Kg}$ and the import of $23.78 \mathrm{Kg}$. These results show an evident outflowing of phytoplankton biomass from the Tampamachoco Lagoon to the Tuxpan River through the La Mata Channel.

SM fluxes showed a similar pattern for Chl-a with higher export than import values. In May the total amount of SM exported to the river was $333.99 \mathrm{Kg}$; in September it was $2576.88 \mathrm{Kg}$ (Table 2; Fig.5). Again, the results demonstrate the nature of the La Mata Channel as a means of export of suspended materials to the river. The values of SM exportation observed for May are small compared with those obtained by Hsieh et al. (2010) in $24 \mathrm{~h}$, on two cycles in a semidiurnal tide. Hsieh et al. (2010) obtained -16.089 and 13.491 Tons in January and April, respectively, in the channel of a Taiwan coastal lagoon, similar in size to that of the present study but with urban waste water inflow and mangrove-fringed. The mean result of La Mata Channel for May was $172 \mathrm{Kg}$ of exported SM, by two cycles of a semi-diurnal tide. One diurnal cycle (around $24 \mathrm{~h}$ ) of September SM exportation yielded $674 \mathrm{Kg}$. This value is higher than that of May because of the basin runoff in the rainy season. In September high values of SM transport can be related to the higher water flow speeds that promote the resuspension of sediments that are driven horizontally through the La Mata Channel into the Tuxpan River.

In general the phytoplankton was mainly composed of organisms of marine origin, dominated by diatoms in both seasons (Table 3). This composition indicates a higher influence of neritic than of fresh water in the La Mata Channel. In the phytoplankton samples the presence of Tintinnids was conspicuous, indicating some trophic relation to the planktonic community. May showed a higher variety of diatoms such as Asterionellopsis glacialis, Cylindroteca closterium and Thalassionema nitzschioides. A. glacialis is considered a neritic allochthonous species and $C$. closterium an autochthonous one. Dinoflagellates showed a higher relative abundance than diatoms, especially Protoperidinium, Gonyaulax, Podolampas and Ornithocercus. They were more frequent during sunset sampling and under ebb conditions. Cyanobacteria were represented by the freshwater genera Merismopedia, Anabaena and Microcystis and the marine Trichodesmium. The phytoplankton composition indicates the greater influence of neritic than of fresh water. In September there was little variety of phytoplankton constituents but at higher abundance (not shown) with the dominance of Protoperidinium and Cylindroteca closterium. Hemiaulus hauckii and Thalassiosira appeared in September. Again, the higher abundance of neritic organisms evidenced the marine influence in the $\mathrm{La}$ Mata Channel.

Table 2. Mass of seston and chlorophyll, in $\mathrm{kg}$ for each water flow cycle, as observed in the La Mata Channel, Tampamachoco, Ver, during the May and September sampling periods.

\begin{tabular}{cccccc}
\hline & \multicolumn{2}{c}{ Flow cycle } & \multicolumn{2}{c}{ Supended material } & \multicolumn{2}{c}{ Chlorophyll } \\
\hline \multirow{4}{*}{ May } & & Input & Output & Input & Output \\
& 1st & 37.07 & -101.79 & 4.64 & -12.92 \\
& 2nd & 26.63 & -89.86 & 2.88 & -6.79 \\
& 3rd & 11.92 & -142.34 & 2.44 & -2.96 \\
& Total & 75.62 & -333.99 & 9.96 & -22.67 \\
\hline \multirow{4}{*}{ Sep } & 1st & 158.20 & -927.59 & 7.36 & -58.19 \\
& 2nd & 246.50 & -801.49 & 10.19 & -35.26 \\
& 3rd & 149.50 & -847.80 & 6.23 & -48.53 \\
& Total & 554.20 & -2576.88 & 23.78 & -141.98 \\
\hline
\end{tabular}

\section{DisCUSSION}

Scientific investigation of a complex system like the La Mata Channel is needed to understand its intricate functioning. As demonstrated by our results, it is difficult to explain the number of sea level cycles and the number of current velocity cycles; this system seems to reduce very large scale processes (the basin's drainage, the gulf tides) to "out of phase behaviors". Once the physical and biological processes are understood, the ecosystem services (those useful for human welfare) will be of greater value (FISHER et al., 2009). 
Table 3. General composition of phytoplankton in the La Mata Channel.

\begin{tabular}{|c|c|}
\hline Taxa & Distribution \\
\hline $\begin{array}{l}\text { Diatoms } \\
\text { Achanthes sp } \\
\text { Actinoptichus sp } \\
\text { Asterionellopsis glacialis } \\
\text { Bacteriastrum sp } \\
\text { Chaetoceros constrictum } \\
\text { Chaestoceros curvisetus f. mitra } \\
\text { Cheatoceros diversus } \\
\text { Chaetocers gracilis } \\
\text { Cocconeis placentula } \\
\text { Cocconeis sp } \\
\text { Cylindrotheca closterium } \\
\text { Cyclotella sp } \\
\text { Denticulopsis sp } \\
\text { Diploneis bombus } \\
\text { Ditylum sp } \\
\text { Fragilaria sp } \\
\text { Gomphonema termicum } \\
\text { Gomphonema augur } \\
\text { Goniodoma sp } \\
\text { Grammatophora sp } \\
\text { Gyrosigma sp } \\
\text { Hemiaulus hauckii } \\
\text { Hemidiscus sp } \\
\text { Mastogloia quinquecosta } \\
\text { Melosira nummuloides } \\
\text { Navicula spp } \\
\text { Nitzschia macilenta } \\
\text { Pinnularia sp } \\
\text { Proboscia alataf. indica } \\
\text { Pseudonitzschia pacifica } \\
\text { Raphidiopsis sp } \\
\text { Rhizosolenia setigera } \\
\text { Rhizosolenia shrubsolei } \\
\text { Rhizosolenia stolterfothii } \\
\text { Skeletonema costatum } \\
\text { Surirella sp } \\
\text { Tabellaria sp } \\
\text { Thalassionema nitzschioides } \\
\text { Thalassiosira sp } \\
\text { Thalassiothrix sp }\end{array}$ & $\begin{array}{l}\text { marine } \\
\text { cosmopolitan } \\
\text { cosmopolitan } \\
\text { marine } \\
\text { temperate } \\
\text { cosmopolitan } \\
\text { warm-water } \\
? \\
\text { cosmopolitan? } \\
\text { cosmopolitan } \\
\text { cosmopolitan } \\
\text { brackish-water } \\
\text { tropical } \\
? \\
\text { warm-water } \\
\text { neritic } \\
? \\
\text { wide distribution } \\
\text { wide distribution } \\
\text { temperate } \\
\text { cosmopolitan } \\
\text { warm-water } \\
\text { warm-water } \\
? \\
\text { cosmopolitan } \\
\text { wide distribution } \\
? \\
? \\
? \\
\text { warm-water } \\
? \\
\text { cosmopolitan } \\
\text { wide-distribution } \\
\text { cosmopolitan } \\
\text { cosmopolitan } \\
? \\
\text { fresh-water } \\
\text { cosmopolitan } \\
\text { wide-distribution } \\
\text { warm-water }\end{array}$ \\
\hline $\begin{array}{l}\text { Dinoflagellates } \\
\text { Amphidinium } \mathrm{sp} \\
\text { Ceratium furca var. hircus } \\
\text { Ceratium pentagomum } \\
\text { Gonyaulax } \mathrm{sp} \\
\text { Gymnodinium } \mathrm{sp} \\
\text { Ornithocercus } \mathrm{sp} \\
\text { Peridinium } \mathrm{spp} \\
\text { Podolampas } \mathrm{sp} \\
\text { Protoperidinium } \mathrm{spp}\end{array}$ & $\begin{array}{l}\text { cosmopolitan } \\
\text { coastal } \\
\text { oceanic } \\
\text { wide distribution } \\
\text { wide distribution } \\
\text { wide distribution } \\
\text { wide distribution } \\
\text { oceanic } \\
\text { wide distribution }\end{array}$ \\
\hline $\begin{array}{l}\text { Cyanobacteria } \\
\text { Anabaena sp } \\
\text { Merismopedia sp } \\
\text { Microcystis sp } \\
\text { Trichodesmium sp }\end{array}$ & $\begin{array}{l}\text { freshwater } \\
\text { freshwater } \\
\text { freswater } \\
\text { marine }\end{array}$ \\
\hline
\end{tabular}

It is interesting to note that in May the temperature and current velocity were out of phase by 180 degrees, while in September the figure was 120 degrees. Physically this means that in May the water flowing into the lagoon was colder than that outflowing. In September at the beginning of the flood tide, the temperature fell dramatically by around 3.5 ${ }^{\circ} \mathrm{C}$ and persisted at that level, and during the beginning of the ebb the water temperature abruptly increased by around $3.5^{\circ} \mathrm{C}$ and continued at that level. The coastal sea was cooler than the water inside the lagoon. During both seasons the lagoon water's temperature was warmer than that of sea, thus the lagoon exported warm water to the river and then to the coastal sea.
The behavior of the temperature in May and September is quite similar to that found by Hsieh et al. (2010) in the bay of Tapong (Taiwan), a coastal lagoon connected directly to the sea (not through a river estuary). May salinities were poorly correlated to the current velocity; a slight reduction in salinity was observed during the flood periods and a slight increase during the ebb. During September salinity values were in phase with the current velocity; when the flood tide occurred an increase in salinities was recorded, in contrast with the ebb tide where a reduction was observed.

In May water level oscillations inside the La Mata Channel presented two cycles, whereas three velocity cycles occurred during the same period. In the same fashion for September, surface water levels showed a change from mixed to diurnal tide, while flow velocities showed a diurnal pattern with three cycles. A similar behavior is to be observed in the study of Dyer et al. (1992) on the channel that links the Sungai Merbok estuary (Malaysia) to the ocean.

The salinity flux results (Table 1) in the La Mata Channel reveal that the amount of salt that enters is smaller than that which flows out; the gross average proportion of salt (influx/outflux) was 0.35 for May and 0.26 for September. Two considerations arose from these results. First, that a reasonable amount of sea water that flows toward the La Mata Channel is entering through Boca Galindo. Second, it is also possible that during the flood phase sea water entered the lagoon below the current meter, mixing with the freshwater inside the channel and lagoon; a process known as the erosion of the salt water wedge, discussed by Dyer et al. (1992) who characterized it as the vertical shear turbulence that might be responsible for the mixing. Ecological considerations on this process call for further research.

During September a conspicuous process is seen exactly during the early flood tide. At the moment when the water current velocity changed from negative to positive (from ebb to flood) a sharp reduction in salinity was observed; this means that river water is introduced into the Tampamachoco Lagoon through the La Mata Channel (that is, the water contained in the path from the coastal sea to the La Mata Channel inlet is carried into the channel). In the La Mata tidal channel sulfur phototrophic bacterioplankton of three families (Rhodospirillaceae, Chromatiaceae and Chlorobiaceae) has been reported in the water column; this group has been associated with polluted waters (NÚÑEZ-CARDONA, 2008). Virus, bacteria, heavy metals, aromatic compounds, detergents - among a large number of substances transported by the Tuxpan River - (BENITEZ; BARCENAS, 1996), are systematically introduced into the Tampamachoco Lagoon in accordance with 
the flow of river water into the La Mata Channel; fortunately the outflow generated by the ebb process acts as a flushing pump to purify the system.

Water velocity values were of the same order as those reported by Valle-Levinson et al. (2001) at the inlet channel of a semiarid coastal lagoon on Guaymas' Bay, Mexico. Tidal velocity asymmetries, defined as occurring when the duration of the outflowing tide exceeds that of the in-flowing tide, have been observed elsewhere; these are mainly due to the combined effects of the mean basin depth, the depths of intratidal shoals and the relative prism volume. In some systems the wind also can modify the difference in the duration of the ebb and flood tides (WANG et al., 2002); those authors also highlighted the importance of asymmetry in the sediment transport dominated by suspended load.

Asymmetry has also been explained as due to the fact that "a fraction of the water that enters the lagoon during flood tide may already have entered it during previous tidal cycles, thereby further contributing to the consistently high level of Chl-a and SM" (PEREIRA-FILHO et al., 2001). Tidal asymmetry for a semi-diurnal neap tide in May had an average duration of $3.2 \mathrm{~h}$, and that for a diurnal spring tide in September one of $6.17 \mathrm{~h}$. It is believed that the entry of water through Boca Galindo and the drainage of the basin in the rainy season (September) enhanced this asymmetry. In the La Mata Channel two extreme scenarios were analyzed, freshwater runoff and spring tidal conditions, though the asymmetry was observed in both seasons. As has already been mentioned, likely the runoff water from the lagoon plays an important role in the asymmetry; during the dry season water flowing out of the lagoon presented high salinities, mostly close to 36 , while during the rainy season they were below 30 .

The temporal variability of Chl- $a$ and SM fluxes reveals a significant exchange between the lagoon, the river and the sea (Fig. 5) The overall results showed that in May the export of Chl- $a$ exceeded the import by 2.3 times, and the SM export exceeded the import by 4.4 times. In September the export of Chl-a was 6 times greater than the import and SM export was 4.6 times the import. In September the Chl-a export was 6.2 times higher than in May and the export of SM 7.7 times that of May. This means that the La Mata Channel serves as an evident means for the exportation of living and nonliving materials, especially in the rainy season.

Odum (1980) proposed three ecosystemlevel hypotheses: "a) tidal subsidy concept; b) the outwelling idea; c) the concept of a detritus-based food chain as the dominant channel of energy flow in estuaries". The outwelling hypothesis states that marsh-estuarine ecosystems produce much more organic material than can be utilized by or stored within the system, and that the excess material is exported to the coastal ocean where it supports near coastal ocean productivity, particularly fisheries.

The first two hypotheses have been demonstrated in the present study. High tidal energy was evidenced in the La Mata Channel by the predominance of the outwelling of salt, Chl-a and SM to the Tuxpan River.

The phytoplankton biomass in the La Mata Channel is exposed to the permanent turbulence of horizontal transport for several hours and then to drastic velocity changes. In view of the fact that phytoplankton swimming speeds range from just below 0.1 to over $0.5 \mathrm{~mm} \mathrm{~s}^{-1}$ (ROSS; SHARPLES, 2008), the phytoplankton continuously transported in the La Mata Channel during the flood and especially in the ebb phases may even be harmed and the organisms (quetas from Chaetoceros colonies, Ceratium's horns, among others) over-dispersed in inadequate environmental conditions (ROTHSCHILD; OSBORN, 1988).

The transport patterns allow us to interpret the channel mechanism as it relates to phytoplankton biomass and the import-export of suspended materials. The water flow along the channel is an effective vehicle for transporting biomass and suspended materials.

\section{Conclusions}

The La Mata Channel is a highly dynamic tidal system on a small spatial-temporal scale. There is a net mass transport, between the coastal lagoon, the river and the adjacent sea, of water, salt, chlorophyll- $a$ and suspended materials at each tidal cycle, in the ebb phases. Besides its local relevance, these observations constitute one of the few reported cases of exchanges between a coastal lagoon, a river and the adjacent sea, as interacting subsystems with short-term variability. Most of the literature only shows the hydrodynamic relationship between estuaries and the coastal ocean on large temporal scales (monthly, seasonal, annual or interannual scales). The hydrodynamic processes, on tidal time scales (i.e. hours), have effects on the horizontal transport of chlorophyll- $a$ and suspended materials; and have been explored less frequently. Tidal velocity asymmetry is a mechanism for the net transport of salt, Chl- $a$ and SM; thus the Tampamachoco coastal lagoon exports relatively warm, salty, chlorophyll and suspended matter rich water to the Tuxpan River through the La Mata Channel.

The flow along the channel was ebbdominated in both seasons with a greater and faster flow volume from the lagoon to the river, and of the longer duration that characterizes current velocity 
asymmetry. Salt transport indicated a net export from the coastal lagoon to the Tuxpan River. Chlorophyll- $a$ showed similar concentration in both sampled seasons. Suspended material concentrations were higher in September. Current velocity asymmetries presented an export mechanism that implies the horizontal transport of phytoplankton biomass and suspended materials with a net export from the lagoon to the river.

\section{ACKNOWLEDGMENTS}

We are grateful to Alejandro Romero and the Comisión Federal de Electricidad (CFE) of Laguna Verde for kindly lending us their current meter. This research project has been supported by the Consejo Nacional de Ciencia y Tecnología (CONACyT) (Grant P220CCOR892506), Universidad Autónoma Metropolitana, Campus Xochimilco and Universidad Nacional Autónoma de México. We thank J. Castro for improving the figures.

\section{REFERENCES}

SMU. Servicio Mareográfico de la UNAM. Estación Tuxpan, Ver., Instituto de Geofísica, Universidad Nacional Autónoma de México. Ciudad Universitaria, México, D.F., 2010.

BENITEZ, J. A.; BARCENAS, S. C. Patrones de uso de los plaguicidas en la zona costera del Golfo de México. In: BOTELLO, A. V.; ROJAS-GALAVIZ, J. L.; BENITEZ, J.; ZARATE-LOMELI, D. (Ed.). Golfo de México contaminación e impacto ambiental: Diagnóstico y tendencias. Campeche: Universidad Autónoma de Campeche, Programa Epomex, Serie Científica, 1996. $666 \mathrm{p}$.

CONTE, D.; BOOR, C. Elementary numerical analysis. An algorithmic approach. New York: McGraw-Hill, 1972. $396 \mathrm{p}$.

CONTRERAS, E. F. Variaciones en la hidrología y concentraciones de nutrientes en el área estuarinolagunar de Tuxpan-Tampamachoco, Ver., México. Biótica, v. 8, n. 2, p. 201-213, 1983.

CONTRERAS-ESPINOSA, F.; CASTAÑEDA-LÓPEZ, O.; GARCIA-NAGAYA, A. La clorofila a como base para un índice trófico en lagunas costeras mexicanas. An. Inst. Cienc. Mar Limnol. UNAM., v. 1-2, n. 21, p. 5566, 1994.

DYER, K. R.; GONG, W. K.; ONG, J. E. The cross sectional salt balance in a tropical estuary during a lunar tide and a discharge event. Estuar. Coast. Shelf Sci., v. 34, n. 6, p. 579-591, 1992.

FISHER, B.; TURNER, R. K.; MORLING, P. Defining and classifying ecosystem services for decision making. Ecological Economics, v. 68, n. 3, p. 643-653, 2009.

FLORES-COTO C.; BECERRIL-MARTÍNEZ, J. A.; ZAVALA-GARCÍA, F.; GRACIA, A.; BURKE, J. S. Shrimp postlarvae immigration during the high current velocity period of the flood tide in the southern Gulf of Mexico. Hidrobiológica, v. 20, n. 1, p. 1-12, 2003.
GÓMEZ-AGUIRRE, S.; SANTOYO-REYES, H. Plancton de Lagunas Costeras XI. Transporte en tres estuarios del noroeste de México (noviembre 1973). Rev. Lat-Amer. Microbiol., v. 17, n. 3, p. 175-183, 1975.

GÓMEZ-GUTIÉRREZ, J.; ROBINSON, C. J. Tidal current transport of epibenthic swarms of the euphausiid Nyctiphanes simplex in a shallow, subtropical bay on Baja California peninsula, México. Mar. Ecol. Progr. Ser., v. 320, p. 215-231, 2006.

HSIEH, W. C.; LEE, H. J.; TEW, K. S.; LIN, C.; FAN, K. S.; MENG, P. J. Estimating nutrient budgets in a coastal lagoon. Chinese Sci. Bull., v. 55, n. 6, p. 484-492, 2010.

HOITINK, A. J. F.; HOEKSTRA, P.; van MAREN, D. S. Flow asymmetry associated with astronomical tides: Implications for the residual transport of sediments. J. Geophys. Res., v.108, n. C10, 3315, doi:10.1029/2002JC001539, 2003.

LORENZEN, C. J. Determination of chlorophyll and pheopigments: spectrophotometric equations. Limnol. Oceanogr., v. 12, p. 343-346, 1967.

LUCAS, L. V.; KOSEFF, J. R.; MONISMITH, S. G.; CLOERN, J. E.; THOMSON, J. K. Processes governing phytoplankton blooms in estuaries. II: The role of horizontal transport. Mar. Ecol. Progr. Ser., v. 187, p. 17-30, 1999.

LUCAS, L. V.; SERENO, D. M.; BURAU, J. R.; SCHRAGA, T. S.; LOPEZ, C. B.; STACEY, M. T.; PARCHEVSKY, K. V.; PARCHEVSKY, V. P. Intradaily variability of water quality in a shallow tidal lagoon: mechanisms and implications. Estuar. Coasts, v. 29, n. 5 , p. $711-730,2006$.

MANN, K. H.; LAZIER, J. R. N. Dynamics of marine ecosystems. Biological-physical interactions in the oceans. Boston: Blackwell Publishing, 2006. 496 p.

MONBET, Y. Control of phytoplankton biomass in estuaries: A comparative analysis of microtidal and macrotidal estuaries. Estuaries, v. 15, n. 4, p. 563-571, 1992.

MOSER, G. A. O.; FLORES GIANESELLA, S. M.; BARRERA ALBA, J. J.; LUVIZON BÉRGAMO, A.; SALDHANA-CORRÉA, F. M. P.; BRUNER DE MIRANDA, L.; HARARI, J. Instantaneous transport of salt, nutrients, suspended matter and chlorophyll-a in the tropical estuarine system of Santos. Braz. J. Oceanogr., v. 53, n. 3-4, p. 115-127, 2005.

NÚÑEZ-CARDONA, M. T. Las bacterias rojas del azufre en ambientes marinos mexicanos. In: SIGNORET, $M$. (Comp.). De las bacterias al clima: un enfoque ecológico. México: Serie Académicos, CBS, UAMXochimilco, 2008. 128 p.

ODUM, E. P. The status of three ecosystem-level hypotheses regarding salt marsh estuaries: tidal subsidy, outwelling and detritus based food chains. In: KENNEDY, V. S. (Ed.). Estuarine Perspectives. New York: Academic Press, $1980.533 \mathrm{p}$.

PEREIRA-FILHO, J.; SCHETTINI, C. A. F.; RÖRIG, L.; SIEGLE, E. Intratidal variation and net transport of dissolved inorganic nutrients, POC and chlorophyll a in the Camboriú river estuary, Brazil. Estuar. Coastal Shelf Sci., v. 53, n. 2, p. 249-257, 2001.

ROBINSON, C. J.; GÓMEZ-AGUIRRE, S. Tidal stream use by the red crab Pleuroncodes planipes in Bahía Magdalena, México. J. Exp. Mar. Biol. EcoI., v. 308, n. 2, p. 237-252, 2004. 
ROSS, O. N.; SHARPLES, J. Swimming for survival: A role of phytoplankton motility in a stratified turbulent environment. J. Mar. Syst., v. 70, p. 248-262, 2008.

ROTHSCHILD, B. J.; OSBORN, T.R. Small-scale turbulence and plankton contact rates. J. Plankton Res., v. 10, n. 3 , p. $465-474,1988$

SÁNCHEZ-SANTILLÁN， N.; DE LA LANZA. G.; SÁNCHEZ-TREJO, R. Influencia del clima sobre la distribución de temperatura, salinidad y clorofila a en una laguna al NW del Golfo de México. Geofísica, v. 47, p. 103-126, 1997.

TOMAS, C. R. Identifying Marine Phytoplankton. San Diego: Academic Press, 858 p. 1997.
VALLE-LEVINSON, A.; DELGADO, J. A.; ATKINSON, L. $P$. Reversing water exchange patterns at the entrance to a semiarid coastal lagoon. Estuar. Coast. Shelf Sci., v. 53, p. 825-838, 2001

WANG, Z. B.; JEUKEN, M. C. J. L.; GERRITSEN, H.; DE VRIEND, H. J.; KORNMAN, B. A. Morphology and asymmetry of the vertical tide in the Westershelde estuary. Cont. Shelf Res., v. 22, n. 17, p. 2599-2609, 2002.

(Manuscript received 09 May 2011; revised 14 April 2012; accepted 25 May 2012) 